The Geographical Journal of Nepal

Vol. 14: 113-130, 2021

DOI: https://doi.org/10.3126/gjn.v14i0.35555

Central Department of Geography,

Tribhuvan University, Kathmandu, Nepal

\title{
Policy issues in informal market place and marketing system in Nepal: Experiences from the cities of Kathmandu Valley
}

\section{Puspa Sharma, PhD}

Associate Professor, Central Department of Geography, Tribhuvan University

Corresponding Email: pus.geog@gmail.com

Received: 29 December, 2020; Accepted: 12 January, 2021; Published: March 2021

\begin{abstract}
Informal market places and marketing systems are important sectors in providing employment and income to the poor residents of Kathmandu Valley, the largest urban agglomeration of Nepal. The informal marketing system is a traditional system and has been operated in the valley since the long. This sector shows unique features in terms of marketing, spatial location, and transformation. In this paper, the salient features of the informal market places and marketing systems prevailing in the cities of Kathmandu valley are portrayed and based on these, five major policy issues are explored and suggested for consideration to the urban government for the better management of the informal market places and marketing systems.
\end{abstract}

Keywords: Informal sector, market place, street traders, employment, income generation

\section{Introduction}

Like most of the large cities of developing countries, Nepal's large cities exhibit unprecedented growth of population and influx of migrant labour. For instance, the Kathmandu Valley with its all 20 urban areas is the largest urban agglomeration in Nepal. ${ }^{1}$ Having nearly 1.5 million, the valley's urban population in the last census of 2011 shared over $58 \%$ of the country's total urban population (CBS, 2012). Over the past six decades (1952-2011), a great transformation has occurred in the physical area of the

\footnotetext{
${ }^{1}$ They include five large cities, viz Kathmandu and Lalitpur Metropolitan cities, Bhaktapur, Kirtipur, and Madhyapurthimi and 15 recently inducted municipalities after 2011. The valley occupies $475 \mathrm{~km}^{2}$.
} 
urban Kathmandu Valley. One of the crucial factors to this change has been the growth of population mainly due to the influx of migrants into the valley. Along with these, there has also been increased in the expenditure on urban utility facilities, government administration functions, health, education, banking, tourism, industries, and expansion of road networks in the valley, as well as to the change in political system (Pradhan, 1988). During the same decades, the valley's urban population grew by over 8 times (from 181,082 to $1,465,000$ ) to which migrants contributed approximately $70 \%$. This overwhelming flow of migrants included both Nepalese and foreigners, particularly Indians (Kansakar, 1984; Skeldon, 1985; Pradhan, 2003; CBS, 2003, 2012; Pradhan, Sharma \& Pradhan, 2020). Also the number of informal or squatter settlements in the valley grew from 17 to 45 along with their population from 3,000 to 13,300 during the years: 1985-2008 (Rabenau, 1990; CARE Nepal, 2008). The recent trend is that when people migrate, they choose larger cities instead of small towns. Thus, bigger cities continue to grow at faster rate than the small towns, creating more challenges to employment in the large cities (ADB, 2010). And there has been so huge magnitude of influx of migrants into the valley cities that the existing formal employment sectors could not absorb most of them. Despite this, however, the migrants' inflow has been continued, creating surplus labour force. Thus, the surplus labour force has no other way but to engage in a variety of jobs related to the informal sector by own means. On the other hand, the small towns suffer from the minimal investments, resulting into inadequate development of physical infrastructure (MoUD/GoN, 2017).

This paper attempts to examine and analyze major critical issues in the informal market places and marketing, primarily based on experiences of the cities of Kathmandu Valley. It also suggests possible measures for better planning of the cities of the valley considering the importance and scope of the informal market place and marketing system. Similarly, it deals with concepts and problems of the informal sector in general as well.

\section{Methods and materials}

The paper is based on the data collected during the field survey of 2015. In addition, information has also been acquired from other urban informal sector studies carried out in Kathmandu Valley, as well as from the governmental organizations particularly on the policies and programmes related to informal sector activities. Relevant analysis of the data and information has been carried out to fulfill the objective of this paper. 


\section{Results and discussion}

\section{The informal market place: Concepts, features and problems}

Urban informal sector could be loosely defined to include activities related to the production and services existing in the cities and towns. In a more rigorous sense, it comprises persons, households and organizations engaged in the production, distribution and giving out of goods and services and thus includes activities related specifically to trade, manufacturing, construction-building, transport, and servicespersonal (hairdressing, laundry, tailoring, repairing, ornaments, carpenter, mason, metal workshops and the like) and professional (fortune teller, traditional healer, herbal medicine).

The term 'informal sector' was in fact originated with W. Arthur Lewis in 1954 to describe employment or livelihood generation primarily in the developing world (Lewis, 1955). It came into limelight with the name of 'informal economy' after the work of Keith Hart in Ghana in 1971 (Hart, 1973) and the work of the International Labour Organization in Kenya in 1972 (ILO, 2002). Since then several scholars have used it with different names such as traditional sector, unorganised sector, invisible market, shadow economy, grey market and so on in different countries across the world to refer to marginal but productive, small-scale and self-employed activities (Sethuraman, 1976, 1981; Souza and Tokman, 1976; Harris, 1978; Moser, 1978; Bromely and Gerry, 1979; Harper and Soon, 1979; Hussmann, 2004). This sector serves as a source for promoting growth, employment and equity objectives and thus one of the means of creating somewhat equitable distribution of income among the urban poor communities.

In Kathmandu Valley lying in the central hills of Nepal (Figure 1), the characteristics and developments of the informal sector are shaped by a range of factors: the growth and urbanization of cities, migration of labour from rural areas, location dynamic, growth of informal enterprises, and municipal authorities' concerns, among many others (Sharma, 2018). In fact, all these features of the informal sector offer measurement and analysis of their relative importance for further planning and development particularly to the municipal governments. 


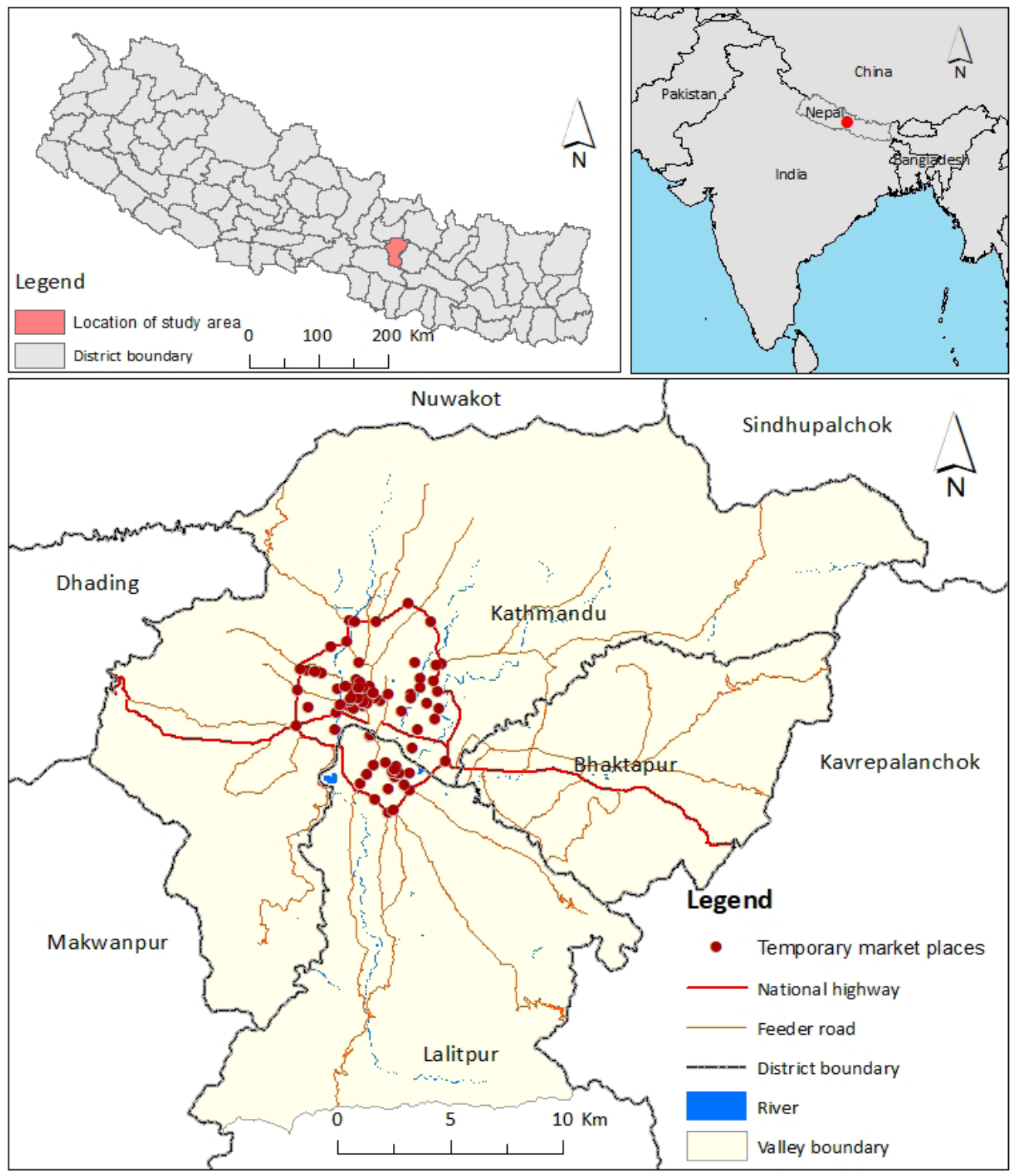

Figure 1: Location of Kathmandu Valley, Nepal

In the cities of the valley, informal market indeed is the largest sector in terms of number, employed population and service provision. One of the principal elements of the valley's urban informal market place is the change of local marketing systems. Over the years, the local marketing systems dealing with the local products have evolved remarkably, which can be attributed primarily to the urban growth. In earlier times, the marketing systems $\|116\|$ 
were traditional and the mobile vendors, locally known as Banjaras were commonly available to meet the local needs by moving themselves in the localities for selling their own agricultural and other craft products (HMG/UN/UNESCO, 1975; Regmi, 1978). This was possibly due to few small market places having retail stores scattered across the valley and regular visits to such market places by the inhabitants on foot. It was difficult and time consuming. The local products included in such trading were seasonal fresh vegetables and fruits, mustard oil, grains, flour, milk products (ghee, curd, cream or Khuwa), rice flake, some spices, handloom cloth, straw mats (Sukuls), baskets, brooms, etc. These commodities were carried by producers themselves by means of locally made Kharpan (suspended a thin, flexible wooden pole balanced across the shoulders) or by porters in large baskets (Dokos) and visited on foot to the open informal market places located in the cities' cores for selling directly to the consumers. This marketing system continued to remain until 1956. Major breakthrough appears to have happened in the valley's marketing system when it saw the first road in 1956, connecting the valley with the Tarai town along the Indian border in the south and replaced the manual conveyance means of goods by the motor vehicles (DHPP, 1972). Thus, the traditional marketing system has gradually been replaced by the modern marketing system due to the growth of urban population and number of market places. Despite this, however, the informal marketing activities particularly the street vendors have increased remarkably since the early 1980 s. The number of informal market places ${ }^{2}$ by locality grew apparently from 13 (with 5 vendors and more) in 1987 to 87 (with 20 vendors and more) in 2018 and likewise the number of vendors therein grew from 317 to 13,935 during the same year interval (Pradhan, 1987; Sharma, 2018).

The feature of the informal market system in the valley could be classified according to various criteria such as form, size and location. Two major types such as sedentary market place occupying fixed sites and itinerant traders with no fixed locations could be categorized based on the form of the informal market system. The former, in terms of number of participants, usually employing family members is being preponderantly larger than the latter (employs only a single family member). In the latter type, the vendors cannot remain as viable institution at a fixed location because of widely diffused effective purchasing power over the city. So, the sellers become mobile and visit other localities or market places to seek potential customers for marketing their products. Such vendors comprised migrants coming particularly from the Tarai and northern border parts of India (Pradhan, 1987). However, both types operate trade business usually at the sites such as street pavements, open spaces, walkways, street junctions or overhead bridges, where there are often crowds of pedestrians from early morning through evening, but disappear during the night and so they are known as "invisible markets". The varieties

${ }^{2}$ In fact, almost all localities or toles of the cities contain petty vendors of varied number. 
of goods and services for selling can be grouped into: (i) perishable: vegetables, fruits, live animals and their products, (ii) grocery, (iii) clothes, (iv) food and beverages, (v) durable goods, and (vi) personal and repairing services. Varieties of these goods vary by time shift and choice of consumers. For instance, perishable, foods and beverages are traded often in the morning and evening shifts, while marketing of other items occur during the day shift. Further, daily marketing of fresh vegetables in the morning or early evening is very common, which indeed appears to have continued since the long. This may be due to the lack of storing or refrigerator particularly among the poor consumers. Another change in the informal market is the entry of consumer goods produced by home-based enterprises due to mainly the emergence of supermarkets and departmental stores in the recent years.

The rapid urban growth has given rise to a number of other types of informal activities, besides informal marketing. They include informal activities related to building construction (mason, contractor, carpenter, painter, plumber, electrician and the like), transportation (pushcart, rickshaw, porter), personal service (hairdresser, laundry, tailoring, repairing, metal scraper, wastes collector) and home-based industry or craft works (blacksmith, goldsmith, silversmith, iron/aluminum, straw, bamboo, cotton, wool, herbs, and agri and dairy produce). The employment provided by these activities is estimated to be substantial, though the information on them is extremely lacking.

However, the informal market places often face problems in operating business. For most of the vendors, the main problem is the harassment by the municipal authorities who either often used to drive out them from the traditional or recent marketing sites or to confiscate their goods and charge them heavy penalty. Other problems relate to environment such as congestion, scattered litters, noise, lacking of sanitation, dusty and muddy, and cluttering. Since the traditional marketing systems have been existed since the long and have employed mostly the urban poor, all those problems of the informal market places need to be improved and managed by the municipal authorities by designing and initiating plans such as operation of vending through certain accessible localities across the cities with providing basic sanitation and pavement facilities, norms and standards, time allocation, litters management, and levying reasonable amount for occupancy of the site by vendors, as well as by regular monitoring.

Based on these unique features of the urban informal market places and marketing systems, the following five major issues could be forwarded for the urban government's policy consideration in order to further improving of the management of the informal market place and marketing systems in the cities of the Valley. 


\section{Policy issues in the informal market place and marketing systems}

Informal activities particularly market places and marketing systems are an essential and unavoidable sectors in the cities of developing countries. In Nepal, they are even more important as the large cities continue to grow primarily due to migrants in search of jobs and other opportunities and facilities and a weak industrial base. The government has made some efforts to address the issues in the informal marketing systems. For instance, now-a-days the municipal government has started to allow the traders to operate trading activities at the public places within the municipal boundary to generate income. Provision has also been made for the municipal authorities to regulate the temporary market places and vendors for operation upon levying certain fees according to time shift, occupancy of site-area, etc. (MLD, 1999). The National Urban Policy, 2007 and the National Plan, 2008 incorporated efforts to include the informal activities into urban development mainstream and to identify locations for operating informal trading activities through encouraging them by providing essential facilities such as skill training, credit, and the like (DUDBC, 2007; NPC, 2007). Following these policies and acts, Kathmandu metropolis has made guidelines to regulate the informal market places and street vendors (KMC, 2007). However, despite these efforts, studies so far available indicate that the informal market places and marketing systems have not been improved so far, but rather they are disorganized and haphazard due to mainly weak implementation of the regulations and often change in the rules and regulations (Pradhan, 1987; Sthapit, 1999; CIUD, 2006; Dawadi, 2008; Sharma and Pradhan, 2017; Sharma, 2018).

It is argued that there is no way but to think of further planning, management and regulation of the informal marketing activities in the cities of the Kathmandu Valley. The importance of the informal sectors of the Kathmandu Valley could be pointed out as below and hence there is a urgent need to devise policy measures for further strengthening and management of the informal market places and marketing systems (Sharma, 2018).

\section{Employment generation}

According to ILO (2000), employment in the informal sector is defined to include all jobs of the persons being employed in at least one of the informal sector enterprises, for instance the private unincorporated enterprises owned and operated by individual, or a group of members of the same household. It is argued that the urban informal sector is for providing employment among the urban poor and equity distribution of income. Urban poverty is a crucial problem of developing countries. Poverty is caused by lack of employment opportunities or inadequate incomes. Employment creation 
is thus perceived as the main goal of most poor countries. Small enterprises display a remarkable capacity to absorb labour in full or part time and it is reasonable for government to promote them, or to desist from destroying them. Of several informal sector activities, informal trading is the main and largest sector to employ petty traders and contribute significantly to the functioning of the urban economy (Sanyal, 1988).

In Nepal, the informal sector has predominant role in its economy. It employs over $70 \%$ of the economically active population and contributes around $52 \%$ to the national GDP (CBS, 2008). The Tenth Plan (2002-2007) has recognised its importance in employment generation and poverty alleviation in the country (NPC, 2002). However, there is lack of exhaustive data with the public source to describe features and status of the urban informal sector in the country, except the Nepal Labor Force Survey that made first attempt to gather some data on this sector across the country in 1998 (CBS, 1999).

Available studies exhibit that the people living in slums of the Kathmandu Valley have adopted various types of the informal activities (petty traders, tailoring, weaving, craftsmen, daily wage workers, transport workers, sand and gravel miners, rag pickers, hotel and restaurant workers, teachers) as a means of livelihood and these activities have employed over $90 \%$ of the working population (Dawadi, 2008; Raut, 2008; Pradhan, 2010). A recent study showed over $87 \%$ of the street vendors, mostly migrants being engaged in the informal marketing (Sharma, 2018). Also found were that those involved in these activities were mostly illiterate, semi-skilled or no formal education and training. They learned skills required for their job through apprenticeship system from their elders. They have been the most vulnerable to the lockdown adopted by the government as a measure to control the dissemination of current upsurge of COVID-19 virus and badly affected their livelihood due to lost of their informal activities and finance, capacity building are to be undertaken by the municipal government particularly the marketing activities, which are a major source of employment.

\section{Employment for women}

Women across Nepal often remain without job and mostly engage in farming and household chores. Informal marketing is a valuable alternative source of income and employment opportunities for urban poor, including women in the cities of Kathmandu Valley. The informal marketing is found encouraging women to engage to produce goods based on home-cottage industries, sewing, food preparation, handicrafts and so on (ILO, 2005). Evidence shows that there is an increasing trend of women employed in the informal activities including particularly the street vendors. In the cities of the valley, women employees have out-numbered the women employees in the informal 
market places (Sharma, 2018). The main reason was social security for women, mainly because mobile vendors required special skills such as riding bi-cycles or driving push carts (Thelas) to move from localities through localities until evening as there is no street light in the most parts of the cities. In addition, the women also often needed to look after their families or household chores such as preparing foods and other works at home in the morning and evening. Women were often found in larger number over males in trading of seasonal produce and the goods during special occasions such as festivals, cultural events, etc. around the temples.

Slowly and gradually it is evident that informal trading has reduced dominance of men in work-employment by engaging women. It is also an important sector to empower women by earning on their own. To encourage more women to this sector, the municipal government needs to create amicable working environment for women in the market places, provision of credit often at below market interest rate, skill training, sanitation facility, street lights and market access and creation of women informal sector workers association to speak and raise concerns on their behalf.

\section{Use of local products and meeting of basic needs}

The goods of the informal activities are originated mainly from local area and indigenous craft traditions to satisfy the needs of the people. In earlier times, the traders for the local products such as agricultural and other craft products were made available to meet the local needs by moving themselves from place to place in the Kathmandu Valley (HMG/UN/ UNESCO, 1975; Regmi, 1978). This system still persists today in most cases. The main features are that they use local indigenous technology, skill, resources and equipment. The localised products such as mustard oil, milk cream and purified butter (ghee), rice flake, etc. were made by indigenous technology and skill of the local inhabitants. Further, locally produced straw, bamboo products (mats, baskets, chairs, tables, etc.) or handloom cloth are aesthetically more pleasing at least to an outsider's eye. As such, they create backward linkage for utilising local resources available in the surrounding rural areas, as well as from other places within the country and forward linkage for exporting their products in the towns and cities, where there is demand. 


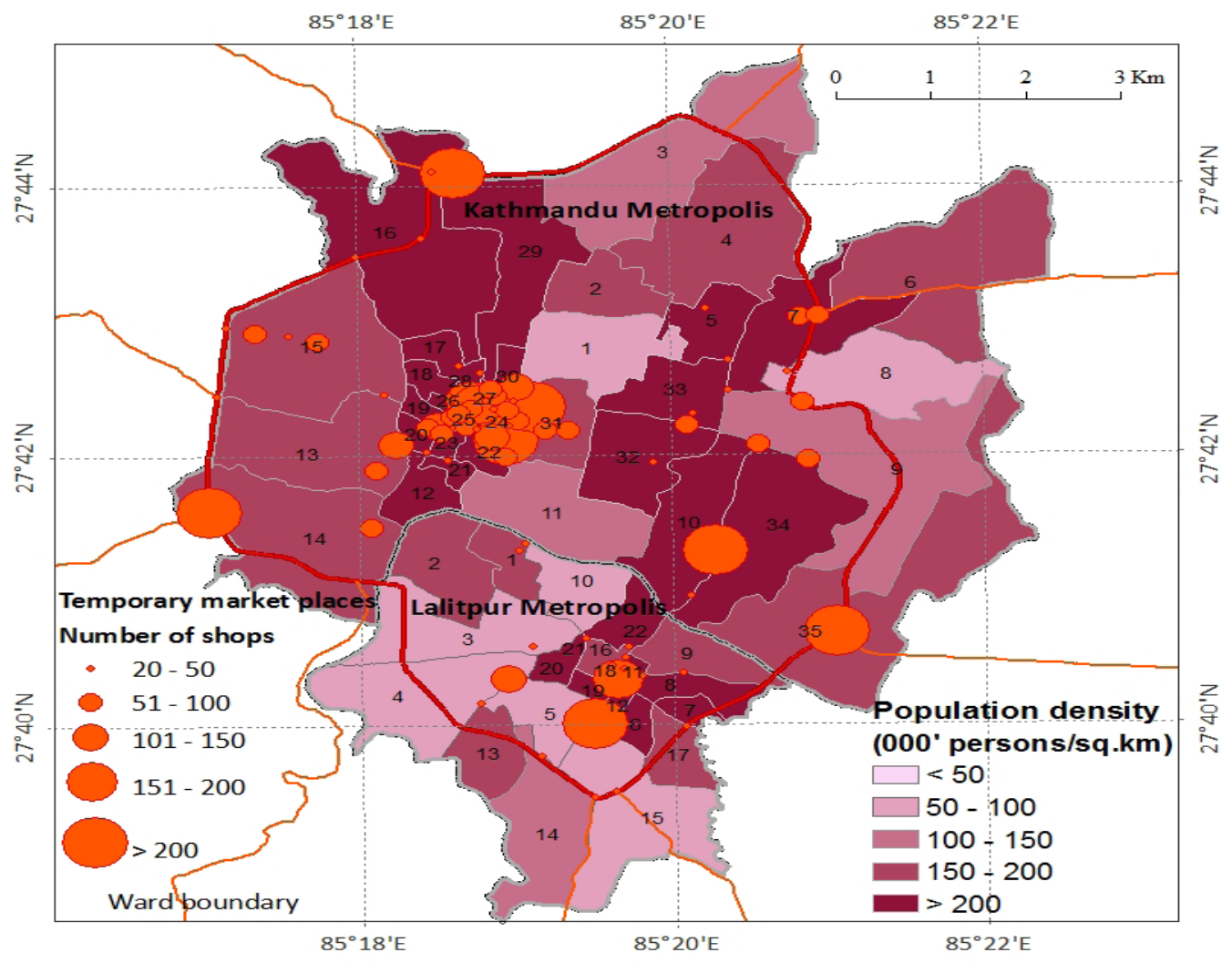

Figure 2: Spatial distribution of informal market places and population density (Source: Sharma, 2018)

The local products of the informal petty enterprises are more likely to satisfy the needs of low-income people. A large part of the basic needs of the poor, including the provision of consumer goods, is provided through street vendors due to mainly two reasons. One is the number of small size market places being scattered across the valley. The price of the basic goods and services of such market places is generally cheaper and small vendors are comparably in large number. Another is that the street vendors carrying goods (comparably small volume and few varieties) by themselves tend to visit house to house for selling them. In doing so, the travel time or cost of the poor people is saved. Evidence is that the distribution of the informal market places is random or scattered at distance apart of approximately 340 meters (Sharma, 2018).

However, there are two distinct patterns of spatial distribution of these market places, such as concentration in the core areas and dispersion in the periphery areas, depending 
on the population distribution or density in the valley (Figure 2). It gives us an opportunity to assess whether the existing locational pattern of the informal market places is appropriate for further planning. Thus, it is argued that potential informal market places are to be developed with providing essential basic market development facilities by the municipal government in view of considering support to grow local products.

\section{Managing urban environment}

The urban expansion and the emergence of the informal activities in the Kathmandu Valley's cities have elevated the concern for environment management in a number of ways. For instance, the cities have shown deteriorating urban environment owing to rapid increase in population growth and density; availability of relatively greater opportunities in employment and social care facilities, change in city life styles and consumption patterns, yet lacking of awareness or habits among the inhabitants with regard to dumping wastes in the containers or at the designated sites, haphazard dumping corners scattered over the cities, limited waste disposal containers in the cities, and the municipalities' irregularity in the collection of wastes. There is also lack of regular awareness raising efforts and notice boards about prohibition of waste disposals anywhere on the part of municipalities.

One of the virtues of the informal sector is its participants to engage in recycling waste materials generated in the cities into productive use. It is found that quite large number of the informal workers are engaged in the collection of waste materials such as scrap metals, used bottles, waste paper, spent batteries, used tyres/tubes, wires and the like (CIUD, 2006; CARE Nepal, 2008). Such recycling of materials, besides contribution to employment and physical environment, also lead to conservation of resources. One major concern of wastes management is to reduce volume of wastes at sources before dumping them into the main dumping sites. The rag pickers pick and sort the wastes for selling to the scarp-metals collect centres/traders for recycling. Since most of these activities are carried out without municipal governments' intervention or support, explicit incentives to them can enhance their contribution to the environment. Note that this sector has employed mostly poor adults and young migrants from rural and other areas from within the countries (CARE Nepal, 2008).

One of the problems facing by the street vendors is dust pollution during the dry months and muddy streets during the rainy months. It is seen that there are many dusty and unpaved roads and potholes across the valley's cities due to the snail paced road expansion works as well as lack of regular maintenance of ruined streets. Another problem is that the 
public toilets are extremely limited and their sanitation condition in terms of cleanliness and hygiene is awfully poor. It is essential that the municipal authorities should think for providing solutions to these problems and also need to imparting awareness among the street vendors about maintaining hygienic condition of their living and surroundings. Furthermore, most of the street traders have often encroached upon public uses such as pavements, walkways, parks, alleys, traffic intersections or road junctions in the cities of valley. So, such petty traders are often being harassed by the municipal authorities or by traffic police, creating the feeling of security lapse to them. Such activities, however, can be regularised by providing license, credit facilities, and other incentives to them. This is mainly due to the idea that the municipal authorities should not think 'street vendors' as problems or burden in urban planning and management, but they should think them as 'opportunities'.

The complex nexus of linkages described above seem to pose some conflicts between urban policy measure to improve the urban environment on the one hand and those aimed at improving employment and income in the informal sector, particularly the market places and marketing systems on the other. One consequence of this is that any effort to improve the urban environment by revering the linkages could affect the income and employment situation of the informal sector.

\section{Managing informal market places sites}

One major concern of the city planning is the improper location of the informal market places, which often occupy public space or street sides. The fact is that they have been operating at such sites since the historic time, which however were manageable and essential for marketing service considering the population size of the cities during that time. The number of the market places and vendors has grown substantially along with the rapid growth of population in the cities due to mainly migration. Another feature is the change in location of the market places from old ones to new sites or some tend to disappear due to expansion of streets and other public works.

Available studies indicate that the market places show two basic problems: one refers to encroachment of public space, creating congestion to pedestrians and another is the lack of pavement and drainage system at the sites of the market places, creating problem of dust and mud during the winter and summer rainy season respectively, as well as un-drained waste or rainwater impoundment due to lack of outlets causing stint smell (Dawadi, 2008; Sharma, 2018). Managing and planning of the informal market places should be an essential work and duty of the municipal authorities, as they are the traditional sites for meeting between petty sellers and buyers or consumers. As such, 
they are unavoidable as well as an essential element of the city landscape. Provisions of street drainage facility for storm water and pavement of floor of the market place sites to avoid dust and mud should be an important priority of the city planning and development. Efforts from the private sector to provide market place facility to the vendors to operate trading of perishable goods and other services to local inhabitants in some places of the cities are praiseworthy, but there is also lack of proper pavement of the floor and paths within the market places, which is due to lack of supervision and monitoring or lack of regulations of the municipal authorities.

\section{Conclusion}

Like in most large cities of the developing countries, there is also a growing concern in Nepal about the role and existence of the informal sector with respect to economic, social and spatial development in the cities. According to the ILO (2005), registered economic units are also considered informal when they display characteristics similar to the unregistered economic units in terms of indicators like small size enterprise, adherence to the social security, size of investment, working structure such as tiny space, etc. On the other hand, the informal sector activities including mainly the street vendors tend to create many problems such as environment pollution, congestion, and haphazard throwing of litters. The municipal authorities often regard them as a nuisance and a reason for ugly appearance of the cityscape. Anyway, the working condition in the informal sector is generally poor and therefore it requires for improvement.

It is evident from the above analysis that the role of the informal market places in terms of providing employment and income opportunities among the poor, migrants and disadvantaged groups including women appears to be undoubtedly important in reducing the extent and intensity of poverty, as well as in providing basic goods and services to the local inhabitants of the cities. Because the cities have become major destinations of the most migrants and as a result, change in the spatial, economic, social and environmental settings in the cities is apparent. From the critical geographic perspective, there is a danger with the urban poor, particularly the street vendors in terms of economic, social and cultural livelihoods possibly due to adaptation of urban structural planning adjustments such as land use, road expansions and traffic congestion management by the local governments, though the market place locations are often expressed in terms of the economic and spatial accessibility to the residents of the cities.

The informal market places and marketing of the Kathmandu Valley show unique features. But they also offer a challenge to the urban policymakers with regard to the issues such as improvement of the working conditions and legal and social protection of the 
persons employed in the informal sector; training and skills development; organization of informal sector producers and workers, and development of appropriate regulatory frameworks. Since the street vendors play crucial role in the positive contributions to the urban economy, some policy measures and strategic interventions are needed on the part of the municipal government for managing street vendors into organized market and dignified street vendors. In case of large cities of the country, the plans and policies so far initiated for managing the informal market places and associated aspects are inadequate. Some of the policy measures and acts including local self-governance act, urban policy, town development act, and the street and footpath business guidelines are appropriate and encouraging towards managing or regulating the informal economic activities such as street vendors and also towards the revenue generation from this sector in the cities. On the other hand, the acts described in the environment protection do not allow operating any such activities in open spaces of historical and cultural importance and likewise the public road act and traffic and transportation management act also do not allow to operating any trading activities in the public places or foot-paths from the vehicular and pedestrians flow perspective. Thus, it appears that there are conflicts in the acts and regulations among the different public agencies in regard to manage and regulate the street vendors in public places. There is a question of implementation of all these acts and regulations responsibly and honestly by the concerned stakeholders.

Location dynamics of the informal market places and their participants are important for understanding the spatial distribution, growth and transformation of the market places in the cities. In this paper, effort has been made to analyse the informal market places and street vendors in terms of various aspects such as spatial location of the market places and their attributes, types, size, problems and prospects and historical account in the Kathmandu Valley's cities from the geographical perspective. As there are extremely limited studies on the location structure of the informal economic activities, the number of trading firms and their significance in terms of spatial and temporal planning perspectives in the cities in an exhaustive manner, they can be issues for future research. However, the five major policy issues described in the paper can be helpful to the valley's municipal authorities for consideration in order to formulate and undertake appropriate policies and legal and regulatory frameworks for managing the informal market places and marketing systems. All these would be a complement to contribute to the existing body of literature on the informal market places and marketing systems. 


\section{References}

ADB (2010). Unleashing economic growth: Region-based urban development strategy for Nepal. Philippines: Asian Development Bank.

Bromley, R. \& Gerry, C. (1979). Who are the casual poor? In R. Bromely and C. Gerry (Eds.), Casual work and poverty in Third World cities, 3-23. New York: John Wiley and Sons.

CARE Nepal (2008). Study on status of unemployed slum youths and their possible linkages with job market in greater Kathmandu. Kathmandu: CARE Nepal.

CBS (1999). Nepal labor force survey 1998/99 statistical report. Kathmandu: Central Bureau of Statistics.

CBS (2003). Population monograph of Nepal. vol. II, 121-168. Kathmandu: Central Bureau of Statistics.

CBS (2008). Nepal labor force survey 2008 statistical report. Kathmandu: Central Bureau of Statistics.

CBS (2012). National population and housing census 2011. Kathmandu: Central Bureau of Statistics..

CIUD (2006). Study of street vendors in Greater Kathmandu. Kathmandu: Centre for Integrated Urban Development (CIUD).

Dawadi, G. S. (2008). Efficiency measures in informal street vendors of urban core area of Kathmandu metropolitan city (Unpublished masters' thesis). Institute of Engineering, Tribhuvan University, Nepal.

DHPP (1972). Inventory report of Kathmandu Valley. Kathmandu: Department of Housing and Physical Planning, Ministry of Public Works, Transport and Communications, His Majesty's Government of Nepal.

DUDBC (2007). National urban policy, 2064. Kathmandu: Department of Urban Development and Building Construction (DUDBC), Ministry of Physical Planning and Constructions, Government of Nepal.

Harper, M., \& Soon, T. T. (1979). Small Enterprises in Developing Countries: Case Studies and Conclusions. I.T. Publication, London. 
Harris, B. (1978). Quasi-formal employment structures and behaviour in the unorganized urban economy, and the reverse: some evidence from south India. World Development, 6(9/10), 1077-1086.

Hart, J. K. (1973). Informal income opportunities and urban employment in Ghana. Journal of Modern African Studies, 11(1), 61-89. doi:10.1017/ s0022278x00008089. JSTOR 159873.

HMG/UN/UNESCO(1975). Kathmandu valley: The preservation of physical environment and cultural heritage protective inventory, Vol 1. Kathmandu: Department of Housing and Physical Planning, His Majesty's Government of Nepal.

Hussmanns, R. (2004). Measuring the informal economy: From employment in the informal sector to informal employment, Working Paper No. 53 (December), Geneva: International Labour Office.

ILO (2000). Current international recommendations on labour statistics. Geneva: International Labour Office.

ILO (2002). Women and men in the informal economy. International Labour Organization. ISBN 978-92-2-113103-8. Retrieved 2006-12-18.

ILO (2005). A report on micro and small enterprise policy review in Nepal. Series 7. Kathmandu, Nepal: International Labour Organization (ILO).

Kansakar, V. B. S. (1985). Indo-Nepal migration: Problems and prospects. Contribution to Nepalese Studies, 11(2): 49-69.

KMC (2007). Street and footpath business management guidelines, Kathmandu: Kathmandu Metropolitan City.

Lewis, W.A. (1955). The theory of economic growth. London: Allen and Unwin.

MLD (1999). Local self-governance act, 2055. Kathmandu: Ministry of Local Development, HMG, Nepal.

Moser, C. N. (1978). Informal sector or petty commodity production: Dualism or independence in urban development. World Development, 6: 1041-1064.

MoUD/GoN (2017). National urban development strategy. Ministry of Urban Development, Government of Nepal, Kathmandu.

NPC (2002). Tenth national plan (2002-2007). Kathmandu: National Planning Commission, the Government of Nepal. 
NPC (2007). Three years interim plan (2008-2010). Kathmandu: National Planning Commission, the Government of Nepal.

Pradhan, P. K. (2003). Population growth, migration and urbanisation, and environmental consequences in Kathmandu Valley, Nepal. In: Unruh J, Krol, M and Kliot, N (Eds.), Environmental Change and Its Implications for Population Migrations. The Netherlands: Kluwer Academic Publishers B.V. Dordrecht,.

Pradhan, S. M. (1988). Kathmandu: Metropolitan development and conservation issues. Regional Development Dialogue. 9(3): 203-221.

Pradhan, B., Sharma, P., \& Pradhan, P. K. (2020). Urban growth and environment and health hazards in Kathmandu Valley, Nepal. In: Singh, R. B., Srinagesh, B. and Anand, S. (Ed.), Advances in Geographical and Environmental Sciences: Urban Health Risk and Resilience in Asian Cities. Springer Nature Singapore (e-book): 293-326, doi.org/10.1007/978-981-15-1205-6

Pradhan, P. K. (1987). Fresh vegetables marketing system in Kathmandu City. Tribhuvan University Journal, XIII (2): 69-76.

Pradhan, P. K. (2010). Living condition and livelihoods of the urban poor: Case from greater Kathmandu. Mountain areas and Globalization, (1-16). Switzerland: IGU/UGI July 4-10.

Rabenau, B.V., (1990). Issues in housing development. Kathmandu: Urban Development through local efforts.

Raut, U. B. (2008). Urban agriculture for sustainable urban development in Kathmandu (Unpublished masters' thesis). Institute of Engineering, Tribhuvan University, Kathmandu.

Regmi, M. C. (1978). A study of Nepali economic history (1768-1846). New Delhi: Manjushree Publications.

Sanyal, B. (1988). The urban informal sector revisited: Some notes on the relevance of the concept in the 1980s. Third World Planning Review, 10(1): 65-83.

Sethuraman, S. V. (1976). The urban informal sector: Concept, measurement and policy. International Labour Review, 114(1): 69-81.

Sethuraman, S. V. (Ed.). (1981). The urban informal sector in developing countries: Employment, poverty and environment. Geneva: ILO. 
Sharma, P. (2018). Urban informal sector: street trading and service activities in greater Kathmandu. PhD dissertation, Central Department of Geography/Faculty of Humanities and Social Sciences of Tribhuvan University, Kathmandu.

Sharma, P., \& Pradhan, P. K. (2017). The petty street vendors and their livelihoods of the Kathmandu Valley cities, Nepal. In: Ainong Li, Wei Deng \& Wei Zhao (Eds.), Land Cover Change and Its Eco-environmental Responses in Nepal. Springer Geography. DOI 10.1007/978-981-10-2890-8_1: 359-379.

Skeldon, R. (1985). Population pressure, mobility, and socio-economic change in mountainous environments: regions of refuge in comparative perspective. Mountain Research and Development, 5(3): 233-250.

Souza, P. R., \& Tokman, V. E. (1976). The urban informal sector in Latin America. International Labour Review, 355-365.

Sthapit, D. (1999). Urban information sector in Kathmandu city: A case study of commercial vendors (Unpublished masters' dissertation). Kathmandu: Department of Architecture and Urban Planning, Institute of Engineering. 